\title{
Melittin, a honeybee venom-derived antimicrobial peptide, may target methicillin-resistant Staphylococcus aureus
}

\author{
JI HAE CHOI ${ }^{1}$, A YEUNG JANG ${ }^{1}$, SHUNMEI LIN ${ }^{1}$, SANGYONG LIM $^{1}$, DONGHO KIM ${ }^{1}$, \\ KYUNGHO PARK ${ }^{2}$, SANG-MI HAN ${ }^{3}$, JOO-HONG YEO $^{3}$ and HO SEONG SEO ${ }^{1}$ \\ ${ }^{1}$ Radiation Biotechnology Research Division, Advanced Radiation Technology Institute,
}

Korea Atomic Energy Research Institute, Jeongeup Si, North Jeolla 580-185, Republic of Korea; ${ }^{2}$ Department of Dermatology,

University of California, San Francisco and Northern California Institute for Research and Education, San Francisco,

CA 94121, USA; ${ }^{3}$ Sericultural and Apicultural Materials Division, National Academy of Agricultural Science,

Rural Development Association, Suwon, Gyeonggi-do 441-100, Republic of Korea

Received November 12, 2014; Accepted July 28, 2015

DOI: $10.3892 / \mathrm{mmr} .2015 .4275$

\begin{abstract}
Methicillin-resistant Staphylococcus aureus (MRSA) is difficult to treat using available antibiotic agents. Honeybee venom has been widely used as an oriental treatment for several inflammatory diseases and bacterial infections. The venom contains predominantly biologically active compounds, however, the therapeutic effects of such materials when used to treat MRSA infections have not been investigated extensively. The present study evaluated bee venom and its principal active component, melittin, in terms of their antibacterial activities and in vivo protection against MRSA infections. In vitro, bee venom and melittin exhibited comparable levels of antibacterial activity, which was more marked against MRSA strains, compared with other Gram-positive bacteria. When MRSA-infected mice were treated with bee venom or melittin, only the latter animals were successfully rescued from MRSA- induced bacteraemia or exhibited recovery from MRSA-infected skin wounds. Together, the data of the present study demonstrated for the first time, to the best of our knowledge, that melittin may be used as a promising antimicrobial agent to enhance the healing of MRSA-induced wounds.
\end{abstract}

\section{Introduction}

Staphylococcus aureus is a significant human pathogen causing healthcare-associated and community-acquired infections (1). Antibiotics effectively treat these infections, however, the emergence of methicillin-resistant $S$. aureus

Correspondence to: Dr Ho Seong Seo, Radiation Biotechnology Research Division, Advanced Radiation Technology Institute, Korea Atomic Energy Research Institute, 29 Geumgu Street, Jeongeup Si, North Jeolla 580-185, Republic of Korea

E-mail: hoseongseo@kaeri.re.kr

Key words: methicillin-resistant Staphylococcus aureus, bee venom, melittin
(MRSA) currently presents a challenge to healthcare systems worldwide (2). Globally, 2,000,000,000 MRSA carriers exist, of whom as many as 53,000,000 suffer from overt MRSA infections. In addition, Staphylococcus aureus clones resistant to the antibiotic vancomycin have been identified; and vancomycin is the last known drug to which earlier strains had been uniformly sensitive (3). These organisms are termed vancomycin-intermediate-resistant Staphylococcus aureus and vancomycin-resistant Staphylococcus aureus $(4,5)$. Therefore, it is becoming difficult to treat staphylococcal infections with current chemotherapeutic agents (6).

Honeybee (Apis mellifera L.) venom contains a complex mixture of therapeutic compounds, including antimicrobial peptides, allowing bees to defend their hives against predators and external threats (7). Several biological and pharmacological studies have examined bee venom components for use as potential pain relievers and treatments for inflammatory diseases (8-10). In addition, the antibacterial activities of venom against several human and animal pathogens have been evaluated (11). However, as venom contains certain complex toxic components, its human therapeutic applications have been limited. Previously, the majority of bee venom components have been individually purified and their specific pharmacological activities investigated.

The melittin peptide, the predominant component of bee venom $(40-48 \%$, w/w), has been investigated substantially, and exhibits potent cytolytic and antimicrobial activities (12). Potential actions against bacteria, viruses and cancer cells have been extensively examined in vitro, although the antimicrobial molecular mechanism remains to be elucidated $(13,14)$. However, to date, few investigations of the in vivo antimicrobial activities of melittin have been performed. The present study investigated the antimicrobial activity of melittin from bee venom, and examined whether it can inhibit MRSA infections in vitro and in vivo.

\section{Materials and methods}

Ethical statement. All animal investigations were performed in accordance with the Guidelines for the Care and Use of 
Laboratory Animals of the Ministry of Food and Drug Safety of Korea, and were approved by the Animal Care and Use Committee of the Korea Atomic Energy Research Institute (Jeongeup Si, Korea; IACUC protocol no. 2014-023).

Bacterial strains and reagents. The bacterial strains examined in the present study are listed in Table I. The streptococcal and staphylococcal strains were grown at $37^{\circ} \mathrm{C}$ in Todd-Hewitt broth (BD Biosciences, Franklin Lakes, NJ, USA) supplemented with $0.5 \%(\mathrm{w} / \mathrm{v})$ yeast extract and Tryptic-soy broth (BD Biosciences), respectively. Purified melittin was purchased from Sigma-Aldrich (St. Louis, MO, USA). Synthetic melittin (GIGAVLKVLTTGLPALISWIKRKRQQ) was chemically synthesised by A\&PEP Co., Inc. (DaeJeon, Korea).

Purification of bee venom. Controlled colonies of natural honeybees (Apis mellifera L.) were maintained at room temperature at the National Academy of Agricultural Science (Suwon, Korea). In brief, a bee venom collector apparatus (Chunglin Biotech, Ansan, Korea) was placed on the hive, and the bees that landed on the apparatus were subjected to an electric shock sufficient to cause the bees to 'sting' a glass plate from which dried bee venom was harvested. The collected venom was dissolved in distilled water, centrifuged at $12,000 \mathrm{x}$ g for $10 \mathrm{~min}$ to remove insoluble materials, and stored in a refrigerator until further use (15-17).

Bactericidal assay. Bacteria were harvested at the early log phase $\left(\mathrm{A}_{600}=0.5\right)$ and suspended in phosphate-buffered saline (PBS) at $\sim 10^{8}$ to $10^{10} \mathrm{CFU} / \mathrm{ml}$. Subsequently, the bacterial samples were incubated with the indicated concentrations of bee venom or melittin at $25^{\circ} \mathrm{C}$ for $30 \mathrm{~min}$, and surviving bacteria were evaluated using a plate counting method, as described previously (18). Briefly, samples were serially diluted in PBS and plated onto blood agar (Kisan Bio, Suwon, Korea). Following a $16 \mathrm{~h}$ incubation at $37^{\circ} \mathrm{C}$, the number of surviving bacteria was counted.

Determination of the minimum inhibitory concentration. To determine the minimum inhibitory concentration (MIC), the present study used a micro-dilution broth method, according to the recommendations of the National Committee for Clinical Laboratory Standards (19). In brief, the cells of the experimental bacterial strains were collected in the logarithmic phase of growth, suspended in $30 \mathrm{mM}$ phosphate buffer (pH 7.0) with $60 \mathrm{mM} \mathrm{NaCl}$, and adjusted to an $\mathrm{A}_{600}$ of 0.3 arbitrary units $\left(1 \times 10^{5}\right.$ cells $\left./ \mathrm{ml}\right)$. The bee venom and the melittin samples were dissolved in $10 \mathrm{mM}$ phosphate buffer ( $\mathrm{pH}$ 6.0) with $130 \mathrm{mM} \mathrm{NaCl}$ and $0.2 \%$ (w/v) bovine serum albumin prior to serial dilution. Sample aliquots (10 $\mu \mathrm{l})$ were mixed with the diluted bacterial suspensions (190 $\mu \mathrm{l})$ followed by incubation for $20 \mathrm{~h}$ at $37^{\circ} \mathrm{C}$. Bacterial growth was determined by measurement of the $\mathrm{A}_{650}$ levels using a VICTOR ${ }^{\mathrm{TM}}$ X3 ELISA reader (PerkinElmer, Inc., Waltham MA, USA).

Cytotoxicity assays. The cytotoxic effects of bee venom and melittin on cultured MCF7 cells were evaluated using a Cell Counting Kit-8 (CCK-8; Dojindo Molecular Technologies, Inc., Gaithersburg, MD, USA). The cells were seeded at a density of $5 \times 10^{3}$ cells/200 $\mu \mathrm{l} /$ well into wells of 96 -well round-bottomed plates and allowed to grow for $24 \mathrm{~h}$ at $37^{\circ} \mathrm{C}$, followed by incubation with bee venom or purified synthetic melittin for $6 \mathrm{~h}$ at $37^{\circ} \mathrm{C}$. The culture supernatants $(100 \mu \mathrm{l}$ quantities) were harvested and mixed with $10 \mu \mathrm{l}$ aliquots of CCK-8 solution. Following $3 \mathrm{~h}$ incubation at $37^{\circ} \mathrm{C}$, the optical densities at $\mathrm{A}_{450}$ were measured using the $\mathrm{VICTOR}^{\mathrm{TM}} \mathrm{X} 3$ ELISA reader (PerkinElmer, Inc.).

Mouse intraperitoneal infection. Mouse infection with Staphylococcus aureus was performed, as described previously (20). Bacteria of the USA300 strain (American Type Culture Collection, Manassas, VA, USA) were spectrophotometrically (OPTIZEN POP; Mecasys Co., Ltd., Daejeon, Korea) adjusted to the desired concentration prior to injection, and bacterial numbers were confirmed via serial dilution and Tryptic soy agar plating. The cultured USA300 bacteria were pelleted, washed and suspended in PBS at $0.5 \times 10^{8} \mathrm{CFU} / \mathrm{ml}$. Mice (7-week-old males) of the CD1 strain were obtained from Oriental Bio, Inc. (Seongnam, Korea), with 10 animals per treatment group. The mice were infected with the USA300 strain $(200 \mu \mathrm{l})$ via intraperitoneal (i.p.) injection, followed by i.p. injection of $100 \mu \mathrm{l}$ bee venom or purified melittin $1 \mathrm{~h}$ later. The infected animals were monitored every $3 \mathrm{~h}$ for up to $36 \mathrm{~h}$. The mice were housed in controlled conditions: Temperature, $23 \pm 2{ }^{\circ} \mathrm{C}$; humidity 55 $\pm 10 \%$; light between 07:00 and 19:00. Each group was housed seperately. All animal experiments in the present study adhered to institutional guidelines upon review of the experimental protocol, and were approved by the Institutional Biosafety Committee and the Institutional Animal Care and Use Committee of Korea Atomic Energy Research Institute.

Mouse skin infection. CD1 mice (7-week old; 3 mice/group) were used to examine skin infection. Following the induction of general anesthesia, the dorsal hair was electrically shaved and the skin was cleaned with $70 \%$ (v/v) ethanol. Skin infection was induced via subcutaneous inoculation of $50 \mu \mathrm{l}$ volumes of USA300 suspension $\left(10^{6} \mathrm{CFU} / \mathrm{ml}\right)$ in PBS. Subsequently, bee venom, melittin (purified or synthetic; $100 \mu \mathrm{g}$ in $80 \mu \mathrm{l} \mathrm{PBS}$ ), or sterile PBS was applied once daily to each surface lesion. Lesion progression was monitored at $24 \mathrm{~h}$ intervals for 10 days by measuring the lesion dimensions with callipers (Jeung Do B\&P Co., Ltd., Seoul, Korea), and capturing images using a digital camera (WB5500; Samsung, Seoul, Korea).

Statistical analysis. Data are presented as the mean \pm standard deviation. Statistical analysis was conducted using GraphPad InStat software version 5 (GraphPad Software, Inc., La Jolla, CA, USA). The statistical significance of between-group differences was evaluated using two-tailed Student's $t$-test. $\mathrm{P}<0.05$ was considered to indicate a statistically significant difference.

\section{Results}

Bee venom exhibits a broad specrtum of antimicrobial activity. The present study examined the antibacterial activities of bee venom against the Streptococcus agalactiae, Streptococcus gordonii, Streptococcus pneumonia, Streptococcus epidermidis, Streptococcus bovis and Staphylococcus aureus Gram-positive bacteria. As shown in Fig. 1, when all the 
Table I. Bacterial strains examined in the present study.

\begin{tabular}{|c|c|c|}
\hline Bacterial strain & Description & Source \\
\hline Streptococcus agalactiae CNCTC 10/84 & Clinical isolate, serotype $\mathrm{V}$ & (18) \\
\hline Streptococcus gordonii M99 & Endocarditis clinical isolate & $(21)$ \\
\hline Streptococcus pneumonia TIGR4 & Laboratory strain, serotype IV & $(22)$ \\
\hline Streptococcus epidermidis RP62a & Clinical isolate & Present study \\
\hline Streptococcus bovis NEM760 & Clinical isolate, biotype II & Present study \\
\hline Staphylococcus aureus USA300 (LAC) & Methicillin-resistant clinical isolate & (23) \\
\hline Staphylococcus aureus Newman & Methicillin-resistant clinical isolate & $(23)$ \\
\hline Staphylococcus aureus MW2 & Methicillin-resistant clinical isolate & $(23)$ \\
\hline Staphylococcus aureus MRSA1 & Methicillin-resistant clinical isolate & Present study \\
\hline Staphylococcus aureus MRSA2 & Methicillin-resistant clinical isolate & Present study \\
\hline Staphylococcus aureus ISP4790 & Clinical isolate & $(23)$ \\
\hline Staphylococcus aureus MU50 & Clinical isolate & $(23)$ \\
\hline
\end{tabular}

Table II. MIC of bee venom towards bacterial strains.

\begin{tabular}{lc}
\hline Bacterial strain & MIC $(\mu \mathrm{g} / \mathrm{ml})$ \\
\hline Streptococcus agalactiae CNCTC 10/84 & 6.25 \\
Streptococcus gordonii M99 & 6.25 \\
Streptococcus pneumonia TIGR4 & 3.12 \\
Streptococcus epidermidis RP62a & 0.78 \\
Streptococcus bovis NEM760 & 1.56 \\
Staphylococcus aureus USA300 (LAC) & 0.78 \\
Staphylococcus aureus Newman & 0.78 \\
Staphylococcus aureus MW2 & 1.56 \\
Staphylococcus aureus MRSA1 & 3.12 \\
Staphylococcus aureus MRSA2 & 1.56 \\
Staphylococcus aureus ISP4790 & 6.25 \\
Staphylococcus aureus MU50 & 6.25 \\
\hline
\end{tabular}

MIC is defined as the lowest concentration of bee venom required to cause the optical density (OD) ${ }_{600}$ value to remain constant between 0 and $18 \mathrm{~h}$. MIC, minimum inhibitory concentration.

bacterial strains were treated with the indicated concentrations of bee venom for $30 \mathrm{~min}$, concentration-dependent death of the bacteria was evident. At venom concentrations between 1.25 and $12.5 \mu \mathrm{g} / \mathrm{ml}$, bacterial viability decreased by $>90 \%$. The MIC values of the bee venom ranged between 1.56 and $12.5 \mu \mathrm{g} / \mathrm{ml}$ (Table II). Notably, the USA300 antibiotic-resistant Staphylococcus strain had the lowest observed MIC $(1.56 \mu \mathrm{g} / \mathrm{ml})$.

The present study further examined the antibacterial activities of bee venom against three MRSA clinical isolates. As shown in Fig. 2, the viabilities of all three strains decreased markedly upon treatment with bee venom for $30 \mathrm{~min}$, and no bacteria survived incubation with $100 \mu \mathrm{g} / \mathrm{ml}$ venom. The MIC values for the three MRSA strains ranged between 0.78 and $3.13 \mu \mathrm{g} / \mathrm{ml}$ (Table II). Notably, the methicillin-sensitive Staphylococcus aureus strains (Mu50, ISP479C, PS735, PS736 and PS737) were less susceptible to bee venom
(MIC $=3.13-12.5 \mu \mathrm{g} / \mathrm{ml}$ ), compared with the MRSA strains (Table II), suggesting that bee venom contains antimicrobial molecules, which specifically target MRSA strains.

Bee venom protects against staphylococcal infection. To measure the cytotoxicity of bee venom, human epithelial cells were incubated with venom for $24 \mathrm{~h}$ and cell viabilities were measured using an MTT assay. As shown in Fig. 3, bee venom was not cellulotoxic at a concentration of $0.4 \mu \mathrm{g} / \mathrm{ml}$. In addition, the administration of bee venom in vivo at up to $20 \mathrm{mg} / \mathrm{kg}$ i.p., caused no signs or symptoms of toxicity in the CD1 mice (data not shown).

The i.p injection of $1 \times 10^{8} \mathrm{CFU}$ of the USA300 strain into mice caused bacteraemia and mortality rates of $100 \%$ within $18 \mathrm{~h}$. When the USA300-infected mice were administered with 1.25 or $2.5 \mathrm{mg} / \mathrm{kg}$ bee venom at the time of infection, no protective effect was evident (data not shown). A low dose of USA300 ( $1 \times 10^{7} \mathrm{CFU}$ per mouse) was injected $1 \mathrm{~h}$ following the administration of PBS or bee venom. Notably, all the mice died $18 \mathrm{~h}$ following the injection of USA300 with bee venom, whereas only five mice of the control group had died by $24 \mathrm{~h}$ post-infection (Fig. 4A). These data demonstrated that, although bee venom exhibited a marked antimicrobial effect in vitro, in vivo administration enhanced MRSA propagation and infection.

In addition, the present study examined the protective effect of bee venom in a staphylococcal skin infection model (Fig. 4B). When USA300 was inoculated intradermally and the areas of infected skin treated with PBS or bee venom $(10 \mu \mathrm{g})$ once daily, the abscesses formed by USA300 were $21.3 \pm 4.8$ and $18.8 \pm 6.8 \mathrm{~mm}$ in diameter in the PBS and bee venom groups, respectively, by day 5 , and no significant difference was observed even following 10 days of venom treatment.

Melittin is the major antimicrobial component of bee venom. Bee venom is a complex mixture of proteins, peptides and low-molecular-weight materials. The principal components of the venom are phospholipase A2 (PLA2; 10-12\%, w/w) and the melittin peptide $(40-48 \%$, w/w). The results of the present study confirmed and extended the previous results, demonstrating that 
A

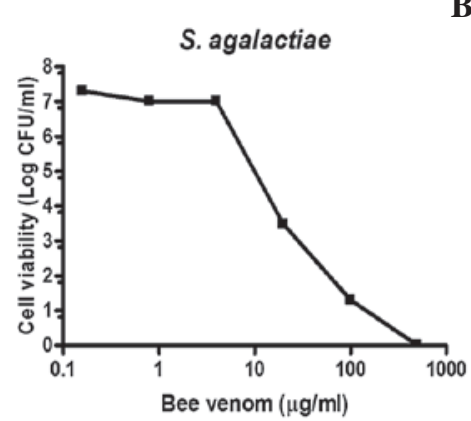

D

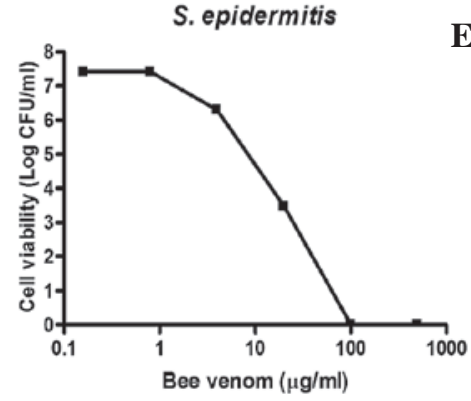

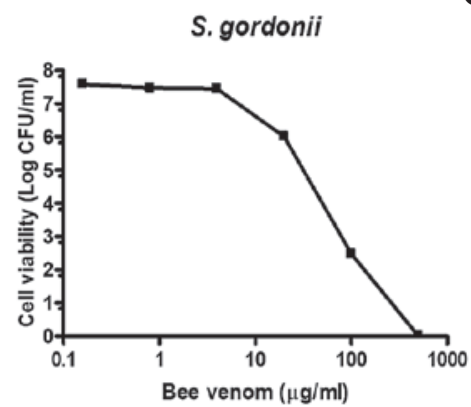

$\mathbf{E}$

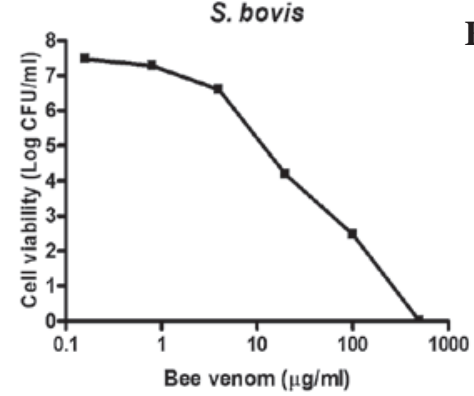

C

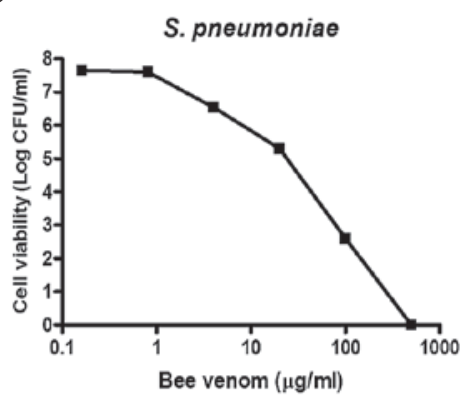

F

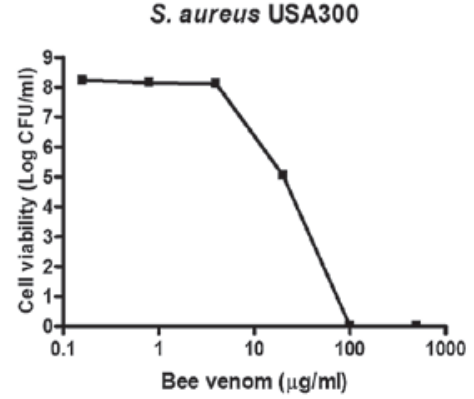

Figure 1. Antimicrobial activities of bee venom against human pathogens. To examine the antimicrobial activities of bee venom against various Gram-positive bacteria strains, the indicated concentrations of purified venom were incubated for $1 \mathrm{~h}$ at room temperature with $100 \mu 1$ quantities of the bacterial suspensions $\left(10^{8}-10^{10} \mathrm{CFU} / \mathrm{ml}\right)$ in phodphate-buffered saline. Cell viability levels were determined by the plating of serial dilutions and colony counting following incubation for 24 h. (A) Streptococcus agalactiae COH1, (B) Streptococcus gordonii DL1, (C) Streptococcus pneumonia TIGR4, (D) Staphylococcus epidermidis 70660, (E) Streptococcus bovis, (F) Staphylococcus aureus USA300. Data are presented as the mean \pm standard deviation.

A

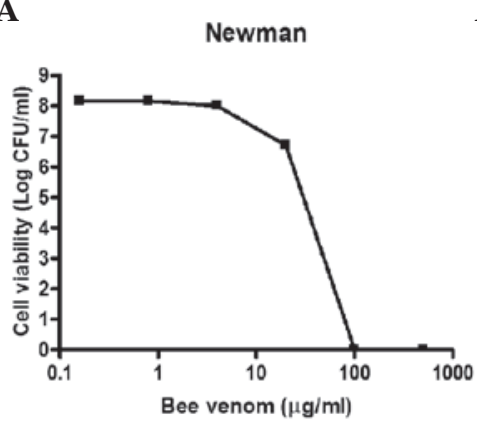

B

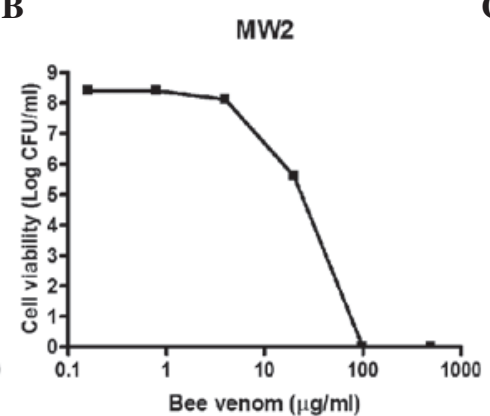

C

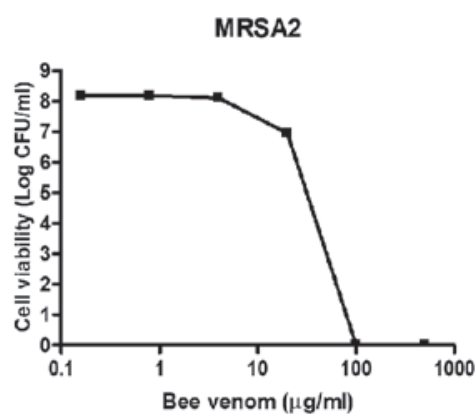

Figure 2. Antibacterial activities of bee venom against clinical isolates of MRSA. To examine the antimicrobial activities of bee venom against various MRSA strains, the indicated concentrations of purified venom were incubated for $1 \mathrm{~h}$ at room temperature with $100 \mu 1$ quantities of the bacterial suspensions $\left(10^{8}-10^{9} \mathrm{CFU} / \mathrm{ml}\right)$ in PBS. Cell viability levels were determined by the plating of serial dilutions and colony counting following incubation for $24 \mathrm{~h}$. (A) Staphylococcus aureus Newman, (B) Staphylococcus aureus Mw2, (C) Staphylococcus aureus MRSA2. Data are presented as the mean \pm standard deviation. MRSA, methicillin-resistant Staphylococcus aureus.

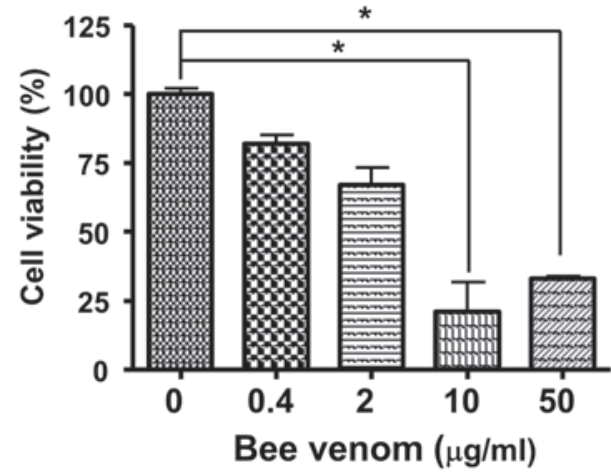

Figure 3. Cytotoxicity of bee venom. Cell viabilities were determined using a Cell Counting Kit- 8 following incubation of the MCF7 cells with the indicated concentrations of bee venom. ${ }^{*} \mathrm{P}<0.01$. Data are presented as the mean \pm standard deviation. $\mathrm{BV}$, bee venom. melittin and PLA2 induced death in a broad range of bacteria, including MRSA strains. As shown in Fig. 5A, treatment of the USA300 and MRSA2 strains with PLA2 did not affect cell viability, whereas the viabilities of the MRSA strains treated with purified melittin decreased to levels comparable to those observed when bee venom was used. To examine whether melittin and PLA2 acted synergistically, two MRSA strains were treated with melittin admixed with PLA2 at various concentrations. When the USA300 and MRSA2 strains were treated with melittin alone $(25 \mu \mathrm{g} / \mathrm{ml})$, the total number of bacteria decreased by 2.5-3 $\log$ CFU (Fig. 5B). However, when the cells were treated with melittin $(25 \mu \mathrm{g} / \mathrm{ml})$ in combination with various concentrations of PLA2, similar results were observed, indicating that PLA2 did not act synergistically with melittin to cause bacterial cell death. 
A

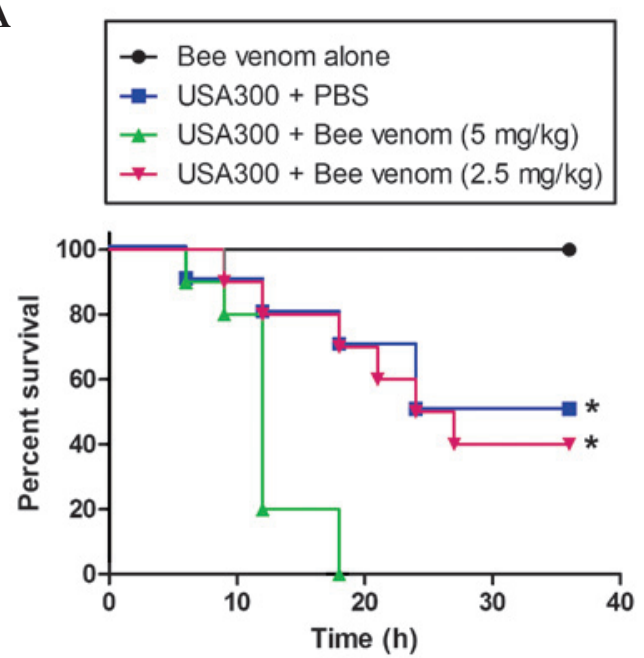

B

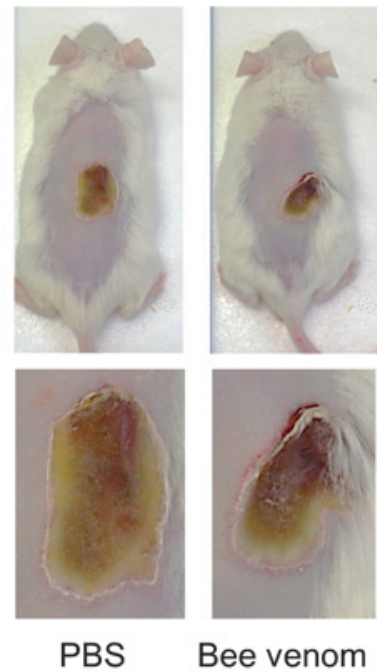

Figure 4. Protection against MRSA infection by bee venom. (A) Kaplan-Meier survival curve of mice inoculated with the MRSA USA300 strain. Staphylococcus aureus USA300 $\left(0.5 \times 10^{8} \mathrm{CFU} / \mathrm{ml}\right)$ in $0.1 \mathrm{ml}$ PBS was injected i.p into CD1 male mice ( $\mathrm{n}=10$ per group). After $1 \mathrm{~h}$, bee venom $(2.5 \mathrm{or} 5 \mathrm{mg} / \mathrm{kg})$ in $0.1-\mathrm{ml} \mathrm{sterile}$ PBS buffer was also injected i.p. Survival rates were monitored every $3 \mathrm{~h}$ for $36 \mathrm{~h}$. ${ }^{*} \mathrm{P}<0.001$. (B) Images of the mice were captured 10 days after skin infection by the USA300 strain. The mice were administered with $10^{6} \mathrm{CFU}$ USA300 in PBS subcutaneously, and bee venom (100 $\mu \mathrm{g}$ in $\left.80 \mu \mathrm{l}\right)$ or sterile PBS was applied to the surface of the skin infection once each day. Lesion progression was examined every day for 10 days, and lesion dimensions were measured daily using callipers. MRSA, methicillin-resistant Staphylococcus aureus; PBS, phosphate-buffered saline; i.p, intraperitoneally.

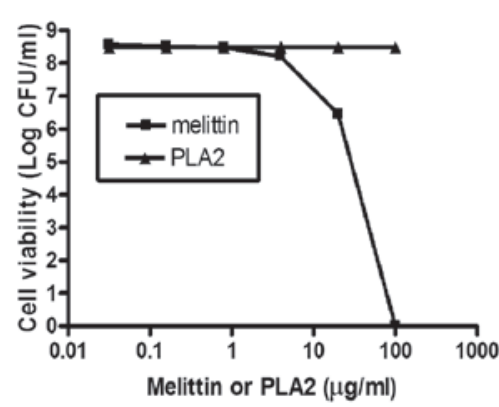

B

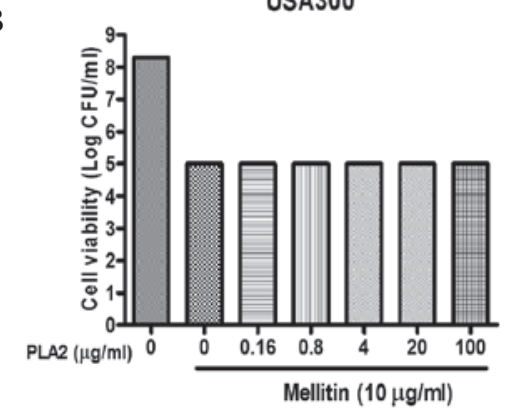

MRSA2

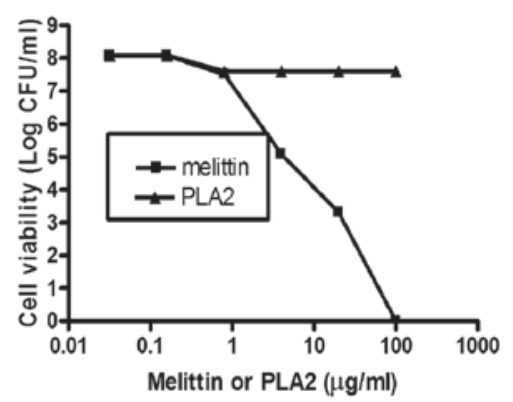

MRSA2

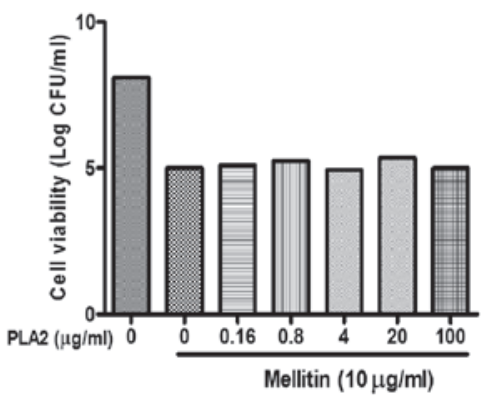

Figure 5. Antibacterial activities of PLA2, melittin or a combination of the two against MRSA strains. (A) Indicated concentrations of purified melittin or PLA2 (in $100 \mu \mathrm{l}$ solution) were incubated for $1 \mathrm{~h}$ at room temperature with $100 \mu 1$ suspensions of the USA300 and MRSA2 strains $\left(10^{8}-10^{9} \mathrm{CFU} / \mathrm{ml}\right)$ in PBS (B) Staphylococcus aureus USA300 and MRSA2 strains were treated with 0-100 $\mu \mathrm{g} / \mathrm{ml} \mathrm{PLA2,} \mathrm{with} \mathrm{or} \mathrm{without} 10 \mu \mathrm{g} / \mathrm{ml} \mathrm{melittin}$, for $1 \mathrm{~h}$ at room temperature in PBS. Cell viability was determined by plating of serial dilutions and colony counting following incubation for $24 \mathrm{~h}$. Data are presented as the mean \pm standard deviation. MRSA, methicillin-resistant Staphylococcus aureus; PLA2, phospholipase A2; PBS, phosphate-buffered saline.

Subsequently, the present study confirmed that synthetic melittin exhibited an antimicrobial activity similar to that of purified melittin. Initially, the toxicities of the two forms of melittin towards human epithelial cells were determined, as described above. As shown in Fig. 6A, synthetic melittin (99.2\% pure) was $\sim 25 \%$ less toxic than the 'purified' melittin (93\% pure). However, the antibacterial activities of the two preparations against the MRSAs were comparable (Fig. 6B).

Protection from staphylococcal infection by melittin. The present study also investigated whether melittin can protect against MRSA skin infections. USA300 bacteria 

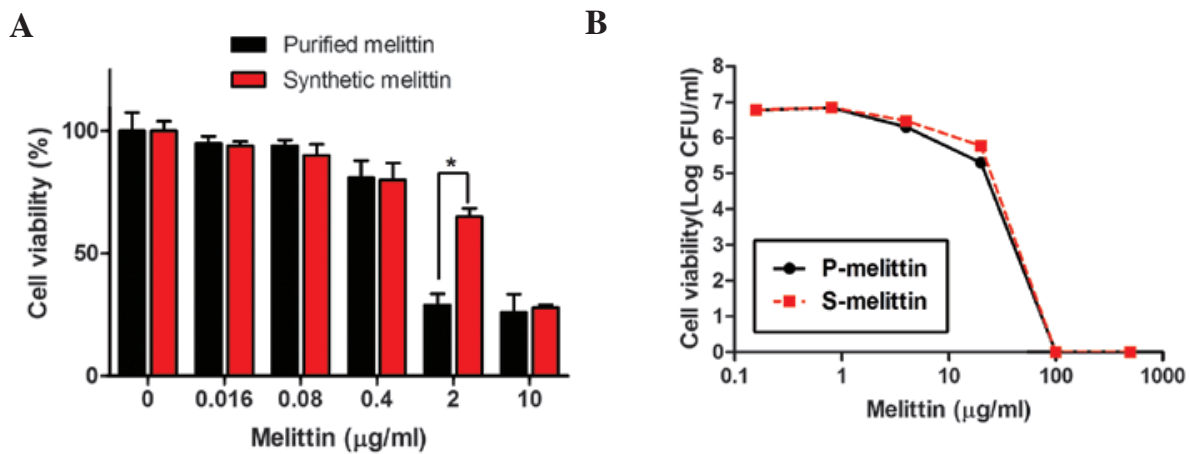

Figure 6. Cytotoxicities and antibacterial activities of purified and synthetic melittin. (A) Cell viabilities were determined using a Cell Counting Kit- 8 . ${ }^{*} \mathrm{P}<0.01$. Data are presented as the mean \pm standard deviation. (B) To examine the antimicrobial activities against USA300, the indicated concentrations of purified and synthetic melittin were incubated for $1 \mathrm{~h}$ at room temperature with $100 \mu \mathrm{l}$ bacterial suspensions in phosphate-buffered saline. Cell viabilities were determined by plating of serial dilutions and colony counting following incubation for $24 \mathrm{~h}$.

A

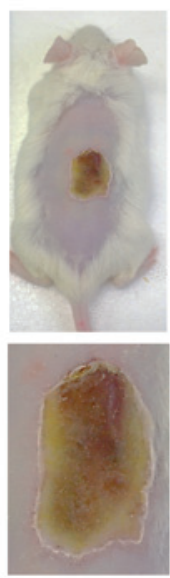

PBS
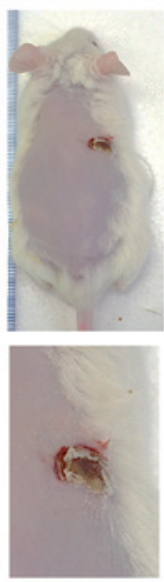

Purified melittin
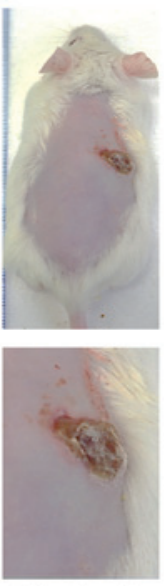

Synthetic

melittin
B

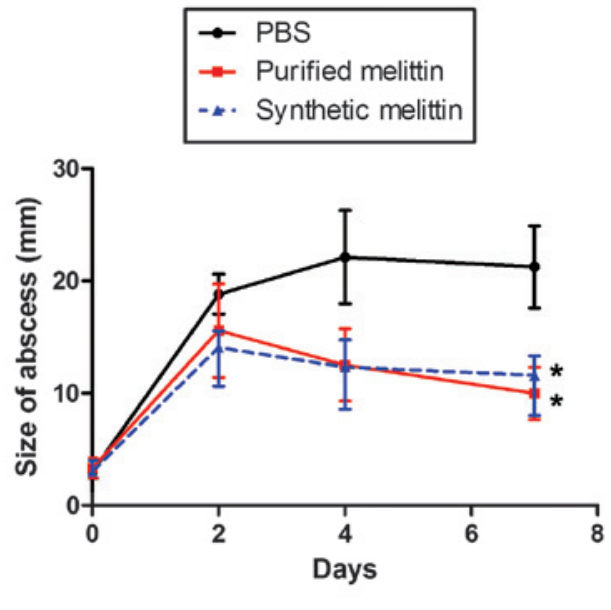

Figure 7. Protection against methicillin-resistant Staphylococcus aureus skin infection by synthetic melittin. (A) Images of the mice were captured 10 days after skin infection by the USA300 strain. Mice were administered with $10^{6} \mathrm{CFU}$ USA300 in PBS subcutaneously, and synthetic melittin (100 $\mu \mathrm{g}$ in $\left.80 \mu 1\right)$ or sterile PBS was applied to the surface of the skin infection once each day. (B) Lesion progression was examined every day for 10 days and lesional dimensions were measured daily using callipers. " $\mathrm{P}<0.001$. Data are presented as the mean \pm standard deviation. PBS, phosphate-buffered saline.

$\left(1 \times 10^{7} \mathrm{CFU} /\right.$ mouse) were injected intradermally into $\mathrm{CD} 1$ mice, which were administered with either PBS, or purified or synthetic melittin $(10 \mu \mathrm{g}) 1 \mathrm{~h}$ post-infection. As shown in Fig. 7, abscesses in the PBS-treated group gradually increased in size to attain a diameter of $22 \pm 6.3 \mathrm{~mm}$ by day 5 . When the infected areas were treated with purified or synthetic melittin once daily for 4 days, the diameters of the abscesses were significantly lower than those measured in the control group.

In addition, the protective effect of melittin was investigated in a model of MRSA bacteraemia (Fig. 8). When a high dose of USA300 was injected i.p., all the mice died following treatment with either PBS or $2.5 \mathrm{mg} / \mathrm{kg}$ melittin after $24 \mathrm{~h}$. However, when the infected mice were injected with $5 \mathrm{mg} / \mathrm{kg}$ melittin $1 \mathrm{~h}$ post-infection, $50 \%$ of the mice survived $>24 \mathrm{~h}$.

\section{Discussion}

Staphylococcus aureus is an important human pathogen, which is responsible for the majority of bacterial soft skin

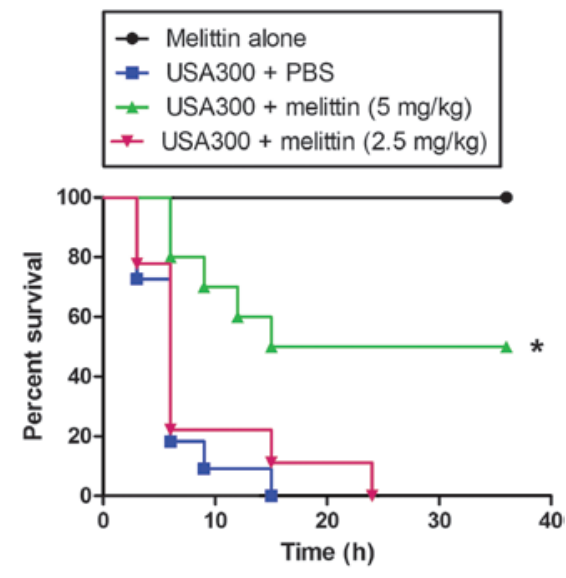

Figure 8. Protection against MRSA infection by synthetic melittin. Kaplan-Meier survival curve of mice inoculated with the MRSA USA300 strain. Staphylococcus aureus USA300 $\left(0.5 \times 10^{8} \mathrm{CFU} / \mathrm{ml}\right)$ in $0.1 \mathrm{ml}$ PBS was injected i.p into CD1 male mice ( $\mathrm{n}=10$ per group). After $1 \mathrm{~h}$, synthetic melittin ( 2.5 or $5 \mathrm{mg} / \mathrm{kg}$ ) in $0.1 \mathrm{ml}$ PBS was injected i.p. Survival was monitored every $3 \mathrm{~h}$ for 36 h. ${ }^{*} \mathrm{P}<0.001$. MRSA, methicillin-resistant Staphylococcus aureus; PBS, phopshate-buffered saline; i.p, intraperitoneally. 
tissue infections and life-threatening infections, including pneumonia, abscesses, endocarditis and infections of surgical sites (2). The rapid spread of MRSA strains is cause for alarm. The rates of MSRA infections are increasing, and MRSA has become the leading cause of invasive illness, resulting in a high rate of mortality worldwide (24-26). Thus, the development of novel therapeutic methods is essential to treat chronic wounds or systemic infections caused by MRSA. In the present study, the in vitro anti-MRSA activities of the natural antimicrobial components of bee venom were investigated.

Bee venom contains several potential antibacterial toxins, including melittin, PLA2, adolpanin, dopamine and hyaluronidase (27). Each component may exert selective and specific actions on human cells and/or bacteria $(16,28)$. Although the bee venom isolated in the present study exhibited potential antimicrobial activities against all the Gram-positive bacteria assessed in vitro, as has been reported in several previous studies $(9,11,29)$, the i.p. administration of venom into MRSA-infected mice caused the a higher mortality rate, compared with that observed in the venom-free controls, suggesting that bee venom actually facilitated MRSA infection. Notably, the PLA2 of bee venom is central to the proinflammatory cascade by activating several physiological and pathogenic immune activities $(30,31)$. In addition, certain hypervirulent bacteria produce and secrete PLA2, which significantly potentiates early-stage infection and inflammation (32-35). The present study also found that, although PLA2 exhibited minimal antibacterial activity, i.p. injection of MRSA-infected mice with PLA2 caused $100 \%$ mortality, whereas only $50 \%$ mortality was observed in the control animals by $24 \mathrm{~h}$, which was also true of the bee venom-treated mice (data not shown). Thus, it is reasonable to suggest that PLA2 increased the susceptibility of at-risk hosts to bacterial infection.

Melittin is the principal component (40-48\%,w/w) of honeybee venom (12), being a small linear peptide of 26 amino acids forming an amphipathic helix with a hydrophobic amino- and hydrophilic carboxyl-terminus. The antibacterial effects of melittin have been widely investigated in vitro (36). In the present study, synthetic melittin exhibited anti-MRSA toxicity in vitro, which was comparable to that of purified melittin. However, the synthetic melittin was less toxic towards human epithelial cells, suggesting that the purified melittin (93\% pure) in the present study contained an uncharacterized component, which is either toxic and/or enhances the toxicity of melittin. Following acquisition of these in vitro results, the present study examined the protective effects of melittin in MRSA-infected mice. Unlike bee venom, melittin exhibited significantly higher protective effects in vivo in the models of bacteraemia and skin infection. Although melittin directly affects microbes by damaging or destabilising cell membranes, the material appears to potentiate the innate immune and anti-inflammatory responses, preventing the development of MRSA systemic infections and facilitating wound healing around infected sites (14,37-39). Melittin exerts anti-inflammatory effects on several types of cell $(38,40,41)$. Melittin suppresses innate immune signaling, including that mediated by nuclear factor- $\kappa \mathrm{B}$ via Toll-like receptor and mitogen activated protein kinase; the synthesis of cyclooxygenase-2; and the expression of inducible nitric oxide synthase $(38,39)$. In addition, melittin stimulates pyrin domain-containing inflammasomes to activate caspase-1 and interleukin $1 \beta$, which crucially recruit neutrophils to sites of expression $(14,40,42)$. Thus, melittin may inhibit MRSA infections by several mechanisms, including the direct induction of MRSA cell death, the downregulation of the innate immune response induced by MRSA and the acceleration of neutrophil recruitment to sites of infection.

Together, the results of the present study demonstrated that bee venom, which is intrinsically toxic, exerts negative effects when used as an anti-MRSA therapy. However, the principal component of bee venom, melittin, exhibits antibacterial effects with minimal toxicity in vitro and in vivo. To the best of our knowledge, the present study is the first to demonstrate that melittin may exert a possible therapeutic role in the treatment of MRSA infections. The mechanism of this effect requires further investigation.

\section{Acknowledgements}

This study was supported by grants from the Nuclear R\&D program of the Ministry of Science, ICT and Future planning (grant no. 523330) to Dr Sangyong Lim and the Next BioGreen21 Program, Rural Development Administration, Republic of Korea (grant. no. PJ009534) to Dr Joo-Hong Yeo.

\section{References}

1. Rasigade JP and Vandenesch F: Staphylococcus aureus: A pathogen with still unresolved issues. Infect Genet Evol 21: 510-514, 2014.

2. Taylor AR: Methicillin-resistant Staphylococcus aureus infections. Prim Care 40: 637-654, 2013.

3. Limbago BM, Kallen AJ, Zhu W, Eggers P, McDougal LK and Albrecht VS: Report of the 13th vancomycin-resistant Staphylococcus aureus isolate from the United States. J Clin Microbiol 52: 998-1002, 2014.

4. Corey GR: Staphylococcus aureus bloodstream infections: Definitions and treatment. Clin Infect Dis 48 (Suppl 4): S254-S259, 2009.

5. Gould IM: VRSA-doomsday superbug or damp squib? Lancet Infect Dis 10: 816-818, 2010.

6. Bassetti M, Merelli M, Temperoni C and Astilean A: New antibiotics for bad bugs: Where are we? Ann Clin Microbiol Antimicrob 12: 22, 2013.

7. Annila I: Bee venom allergy. Clin Exp Allergy 30: 1682-1687, 2000.

8. Son DJ, Lee JW, Lee YH, Song HS, Lee CK and Hong JT: Therapeutic application of anti-arthritis, pain-releasing and anti-cancer effects of bee venom and its constituent compounds. Pharmacol Ther 115: 246-270, 2007.

9. Kim JY, Lee WR, Kim KH, An HJ, Chang YC, Han SM, Park YY, Pak SC and Park KK: Effects of bee venom against Propionibacterium acnes-induced inflammation in human keratinocytes and monocytes. Int J Mol Med 35: 1651-1656, 2015.

10. Lee H, Lee EJ, Kim H, Lee G, Um EJ, Kim Y, Lee BY and Bae H: Bee venom-associated Th1/Th2 immunoglobulin class switching results in immune tolerance of NZB/W F1 murine lupus nephritis. Am J Nephrol 34: 163-172, 2011.

11. Perumal Samy R, Gopalakrishnakone P, Thwin MM, Chow TK, Bow H, Yap EH and Thong TW: Antibacterial activity of snake, scorpion and bee venoms: A comparison with purified venom phospholipase A2 enzymes. J Appl Microbiol 102: 650-659, 2007.

12. Gajski G and Garaj-Vrhovac V: Melittin: A lytic peptide with anticancer properties. Environ Toxicol Pharmacol 36: 697-705, 2013.

13. Adade CM, Oliveira IR, Pais JA and Souto-Padron T: Melittin peptide kills Trypanosoma cruzi parasites by inducing different cell death pathways. Toxicon 69: 227-239, 2013. 
14. Jo M, Park MH, Kollipara PS, An BJ, Song HS, Han SB, Kim JH, Song MJ and Hong JT: Anti-cancer effect of bee venom toxin and melittin in ovarian cancer cells through induction of death receptors and inhibition of JAK2/STAT3 pathway. Toxicol Appl Pharmacol 258: 72-81, 2012.

15. Han SM, Lee GG and Park KK: Acute dermal toxicity study of bee venom (Apis mellifera L.) in rats. Toxicol Res 28: 99-102, 2012.

16. Han SM, Lee KG, Park KK and Pak SC: Skin sensitization study of bee venom (Apis mellifera L.) in guinea pigs and rats. Cutan Ocul Toxicol 32: 27-30, 2013.

17. Han SM, Lee GG and Park KK: Skin sensitization study of bee venom (Apis mellifera L.) in guinea pigs. Toxicol Res 28: 1-4, 2012.

18. Seo HS, Mu R, Kim BJ, Doran KS and Sullam PM: Binding of glycoprotein Srrl of Streptococcus agalactiae to fibrinogen promotes attachment to brain endothelium and the eevelopment of meningitis. PLoS Pathog 8: e1002947, 2012.

19. Clinical and Laboratory Standards Institute: M100-S16, Performance standards for antimicrobial susceptibility testing; 16 th informational supplement. Clinical and Laboratory Standards Institute, Wayne, PA, 2007

20. Ganesh VK, Rivera JJ, Smeds E, Ko YP, Bowden MG, Wann ER, Gurusiddappa S, Fitzgerald JR and Höök M: A structural model of the Staphylococcus aureus ClfA-fibrinogen interaction opens new avenues for the design of anti-staphylococcal therapeutics. PLoS Pathog 4: e1000226, 2008.

21. Bensing BA, Gibson BW and Sullam PM: The Streptococcus gordonii platelet binding protein GspB undergoes glycosylation independently of export. J Bacteriol 186: 638-645, 2004.

22. Seo HS, Cartee RT, Pritchard DG and Nahm MH: A new model of pneumococcal lipoteichoic acid structure resolves biochemical, biosynthetic and serologic inconsistencies of the current model J Bacteriol 190: 2379-2387, 2008.

23. Qian Z, Yin Y, Zhang Y, Lu L, Li Y and Jiang Y: Genomic characterization of ribitol teichoic acid synthesis in Staphylococcus aureus: Genes, genomic organization and gene duplication. BMC Genomics 7: 74, 2006

24. Goldrick BA: MRSA, VRE, and VRSA: How do we control them in nursing homes? Am J Nurs 104: 50-51, 2004.

25. Hebert C and Weber SG: Common approaches to the control of multidrug-resistant organisms other than methicillin-resistant Staphylococcus aureus (MRSA). Infect Dis Clin North Am 25 181-200, 2011.

26. Todd B: Beyond MRSA: VISA and VRSA: What will ward off these pathogens in health care facilities? Am J Nurs 106: 28-30, 2006.

27. Park D, Jung JW, Lee MO, Lee SY, Kim B, Jin HJ, Kim J, Ahn YJ, Lee KW, Song YS, et al: Functional characterization of naturally occurring melittin peptide isoforms in two honey bee species, Apis mellifera and Apis cerana. Peptides 53: 185-193, 2014.

28. Palm NW and Medzhitov R: Role of the inflammasome in defense against venoms. Proc Natl Acad Sci USA 110: 1809-1814, 2013.
29. Fennell JF, Shipman WH and Cole LJ: Antibacterial action of a bee venom fraction (melittin) against a penicillin-resistant staphylococcus and other microorganisms. USNRDL-TR-67-101. Res Dev Tech Rep 5: 1-13, 1967

30. Putz T, Ramoner R, Gander H, Rahm A, Bartsch G, Bernardo K, Ramsay $\mathrm{S}$ and Thurnher M: Bee venom secretory phospholipase A2 and phosphatidylinositol-homologues cooperatively disrupt membrane integrity, abrogate signal transduction and inhibit proliferation of renal cancer cells. Cancer Immunol Immunother 56: 627-640, 2007.

31. Carballido JM, Carballido-Perrig N, Schwärzler C and Lametschwandtner G: Regulation of human T helper cell differentiation by antigen-presenting cells: The bee venom phospholipase A2 model. Chem Immunol Allergy 91: 147-158,2006.

32. Lapointe S, Brkovic A, Cloutier I, Tanguay JF, Arm JP and Sirois MG: Group V secreted phospholipase A2 contributes to LPS-induced leukocyte recruitment. J Cell Physiol 224: 127-134, 2010.

33. Sitkiewicz I, Stockbauer KE and Musser JM: Secreted bacterial phospholipase A2 enzymes: Better living through phospholipolysis. Trends Microbiol 15: 63-69, 2007.

34. Hunt CL, Nauseef WM and Weiss JP: Effect of D-alanylation of (lipo) teichoic acids of Staphylococcus aureus on host secretory phospholipase A2 action before and after phagocytosis by human neutrophils. J Immunol 176: 4987-4994, 2006.

35. Koprivnjak T, Peschel A, Gelb MH, Liang NS and Weiss JP: Role of charge properties of bacterial envelope in bactericidal action of human group IIA phospholipase A2 against Staphylococcus aureus. J Biol Chem 277: 47636-47644, 2002.

36. Fennell JF, Shipman WH and Cole LJ: Antibacterial action of melittin, a polypeptide from bee venom. Proc Soc Exp Biol Med 127: 707-710, 1968

37. Park JH, Kim KH, Lee WR, Han SM and Park KK: Protective effect of melittin on inflammation and apoptosis in acute liver failure. Apoptosis 17: 61-69, 2012.

38. Park HJ, Lee HJ, Choi MS, Son DJ, Song HS, Song MJ, Lee JM, Han SB, Kim Y and Hong JT: JNK pathway is involved in the inhibition of inflammatory target gene expression and NF-kappaB activation by melittin. J Inflamm (Lond) 5: 7 , 2008.

39. Moon DO, Park SY, Choi YH, Kim ND, Lee C and Kim GY: Melittin induces Bcl-2 and caspase-3-dependent apoptosis through downregulation of Akt phosphorylation in human leukemic U937 cells. Toxicon 51: 112-120, 2008.

40. Sommer A, Fries A, Cornelsen I, Speck N, Koch-Nolte F, Gimpl G, Andrä J, Bhakdi S and Reiss K: Melittin modulates keratinocyte function through $\mathrm{P} 2$ receptor-dependent ADAM activation. J Biol Chem 287: 23678-23689, 2012

41. Dempsey CE: The actions of melittin on membranes. Biochim Biophys Acta 1031: 143-161, 1990.

42. Kim SJ, Park JH, Kim KH, Lee WR, Kim KS and Park KK: Melittin inhibits atherosclerosis in LPS/high-fat treated mice through atheroprotective actions. J Atheroscler Thromb 18: 1117-1126, 2011. 